\title{
Proportions of sugarcane and babassu mesocarp bran in diets for feedlot cattle
}

\author{
Wescley Faccini Augusto', Glauco Mora Ribeiro², João Restle ${ }^{1,4}$, Regis Luis Missio ${ }^{3^{*}}$, José \\ Neuman Miranda Neiva ${ }^{2}$, Fabrícia Rocha Chaves Miotto ${ }^{2}$, Higor Patrick Sousa Lopes Rocha ${ }^{1}$ \\ ${ }^{1}$ Universidade Federal do Tocantins, Escola de Medicina Veterinária e Zootecnia, Programa de Pós-graduação em Ciência Animal Tropical, \\ Araguaína, TO, Brazil. \\ 2 Universidade Federal do Tocantins, Escola de Medicina Veterinária e Zootecnia, Araguaína, TO, Brazil. \\ ${ }^{3}$ Universidade Tecnológica Federal do Paraná, Departamento de Agronomia, Pato Branco, PR, Brazil. \\ ${ }^{4}$ PVNS Capes fellow.
}

\begin{abstract}
The objective of this study was to evaluate the production performance of feedlot cattle fed diets containing chopped sugarcane ratios (580 or $380 \mathrm{~g} / \mathrm{kg}$ of diet dry matter) as roughage and levels of inclusion of babassu mesocarp bran (BMB; 420 to $620 \mathrm{~g} / \mathrm{kg}$ of concentrate dry matter). Twenty-four young Nellore bulls with $321 \pm 23 \mathrm{~kg}$ initial body weight, at 22 months of age, were used in a completely randomized experimental design with treatments in a $2 \times 2$ factorial arrangement and six replicates. Dry matter intake $(21.71 \mathrm{~g} / \mathrm{kg}$ of body weight), average daily gain $(1.46 \mathrm{~kg} /$ day $)$, and cold carcass weight $(232.59 \mathrm{~kg})$ were not changed by proportion of sugarcane or BMB level. The proportions of sugarcane and BMB levels did not change the apparent digestibility of the diets, except the digestibility of neutral detergent fiber, which was lower in the diet associating the lowest levels of sugarcane and BMB. Increasing proportions of sugarcane reduced subcutaneous fat thickness from 2.89 to $1.91 \mathrm{~mm}$. Carcass commercial primal cuts were not affected by variation factors. Inclusion of babassu mesocarp bran enables the use of larger proportions of sugarcane as a result of the increased digestibility of the fiber fraction of feedlot cattle diets without changing the performance and main carcass traits of these animals.
\end{abstract}

Key Words: carcass primal cuts, carcass weight, digestibility, dry matter intake, weight gain

\section{Introduction}

Babassu mesocarp bran (BMB) is an important byproduct originating from the processing of the coconut of babassu, a natural palm tree in the Brazilian tropical region and Central America. Babassu has gained international prominence for its potential for biodiesel production, particularly because babassu forests produce 10.7 billion tons of fruit per year (Teixeira and Carvalho, 2007; Teixeira, 2008). The babassu coconut is used to generate several products for human consumption, such as flour, oil (from which biodiesel is obtained), and bran, used in animal feeding. The babassu mesocarp bran is produced from its mesocarp ( $23 \%$ of the fruit) and has a great regional supply

Received: July 7, 2016

Accepted: February 13, 2017

*Corresponding author: regisluismissio@gmail.com

http://dx.doi.org/10.1590/S1806-92902017000800005

How to cite: Augusto, W. F.; Ribeiro, G. M.; Restle, J.; Missio, R. L.; Neiva, J. N. M.; Miotto, F. R. C. and Rocha, H. P. S. L. 2017. Proportions of sugarcane and babassu mesocarp bran in diets for feedlot cattle. Revista Brasileira de Zootecnia 46(8):657-663.

Copyright (C 2017 Sociedade Brasileira de Zootecnia. This is an Open Access article distributed under the terms of the Creative Commons Attribution License (http://creativecommons.org/licenses/by/4.0/), which permits unrestricted use, distribution, and reproduction in any medium, provided the original work is properly cited. at a low cost, which has promoted its use in animal feeding (Silva et al., 2012).

Nutritionally, the babassu mesocarp bran is characterized as fibrous feed with high energy content, but with reduced particle size, which determines the high passage rate through the digestive tract of ruminants. Research carried out with this byproduct in ruminant has focused mainly on inclusion levels replacing corn grain in diets (Miotto et al., 2012; Silva et al., 2012) and recently evolved to the assessment of this feed replacing corn in diets with different levels of concentrate (Cruz et al., 2014) and/or associated with the processing of corn grain (Santana et al., 2015). Recently, because of the good results when used in moderate dietary inclusion levels, this byproduct has been evaluated in association with other feedstuffs, e.g., pearl millet (Alencar et al., 2015). Overall, results from these studies have shown that, at moderate levels in diets, BMB provides similar animal performance and carcass traits in relation to corn, lowering the feed cost (Cruz et al., 2014, 2015; Alencar et al., 2016).

In this scenario, sugarcane is of great use in tropical regions of Brazil and is characterized by a high indigestible fiber content and a low passage rate (Magalhães et al., 2006), contrasting with the BMB characteristics (small particle size and high passage rate) (Miotto et al., 2013). 
Thus, the animal response to BMB inclusion in diets with a higher sugarcane content can be improved by increasing the fiber digestibility, increasing the rumen retention of smaller BMB particles. At the same time, the high passage rate of BMB can compensate for the low passage rate of sugarcane, increasing dry matter intake and the performance of animals on sugarcane-based diets. As such, BMB may totally or partially overcome the main limitation of the use of sugarcane in beef cattle diets, which is the reduced intake (Pires et al., 2010a).

The objective of this study was to evaluate the performance of feedlot cattle fed diets containing proportions of fresh sugarcane as the only roughage and $\mathrm{BMB}$ inclusion levels in the concentrate.

\section{Material and Methods}

The experiment was conducted from July to October 2011, in Araguaína, TO, Brazil ( $07^{\circ} 11^{\prime} 28^{\prime \prime} \mathrm{S}$ and $\left.48^{\circ} 12^{\prime} 26^{\prime \prime} \mathrm{W}\right)$. Procedures performed in this experiment were approved by the local Ethics Committee for Animal Experimentation (case no. 23101001307/2013-18).

Twenty-four young Nellore bulls, at 22 months of age, with an initial average body weight of $321 \pm 23 \mathrm{~kg}$, were kept in individual concrete floor stalls $\left(12 \mathrm{~m}^{2}\right)$ equipped with feed and water troughs. At the beginning of the adaptation phase (14 days), all animals were dewormed and supplemented with vitamins $\mathrm{A}, \mathrm{D}$, and $\mathrm{E}$.

Four diets were formulated to meet the requirements for growth and finishing $(1.20 \mathrm{~kg} /$ day $)$ of young Nellore bulls according to Valadares Filho et al. (2010). These diets included chopped sugarcane as forage and concentrates composed mainly of corn grain, babassu mesocarp bran (BMB), and soybean meal (Table 1). Sugarcane was harvested with 12 months of regrowth and shredded to obtain a particle size of $8-10 \mathrm{~mm}$. The babassu mesocarp bran was obtained commercially by grinding the mesocarp of babassu fruit until $96 \%$ of particles were smaller than $1.18 \mathrm{~mm}$ in diameter (Penn State Particle Size Separator). Treatments were distributed in a factorial arrangement involving two proportions of sugarcane (high or low) and two BMB inclusion levels (Table 2).

Animal performance was measured for 98 days, which consisted of 14 days of adaptation to diet and stalls and 84 days of data collection. Animals were fed at 09.00 and $16.00 \mathrm{~h}$ ad libitum and the amount supplied was adjusted to allow for $10 \%$ as orts (dry matter (DM) basis). Animals fasting for 14-16 $\mathrm{h}$ were weighed at the beginning and end of the evaluation period. To obtain the average feed intake, feed and orts were weighed daily. Throughout the performance test, samples of ingredients and orts from each animal and ingredients of feed concentrates from mixture preparations were collected weekly to form representative samples.

Feces for the digestibility trial were collected during the last three days of the experimental period. Feces were collected $(300 \mathrm{~g})$ manually after spontaneous defecation and before the fecal bolus reached the floor of the pen, with animals monitored from $06.00 \mathrm{~h}$ until the collection of the sample from the last animal. For the digestibility trial and analysis of nutrients, samples were pre-dried in a forced-air oven at $55{ }^{\circ} \mathrm{C}$ for $72 \mathrm{~h}$ and ground through a $1-\mathrm{mm}$ sieve. From the three ground samples, a composite sample was made and stored in plastic containers for subsequent laboratory analyses. The fecal dry matter excretion was estimated using indigestible neutral detergent fiber (iNDF), according to the methodology of Cochran et al. (1986). The iNDF contents of the samples of feces, feed (roughage and ingredients of the concentrate), and orts were obtained after in situ rumen incubation for $240 \mathrm{~h}$ (Casali et al., 2008). The fecal output ( $\mathrm{kg}$ of DM/day) was calculated as follows: iNDF intake/iNDF in feces. Digestibility was calculated by the following expression: apparent digestibility of nutrients $=[($ nutrient intake - nutrients excreted $) /$ nutrient intake].

Table 1 - Chemical composition of ingredients ( $\mathrm{g} / \mathrm{kg}$ of dry matter)

\begin{tabular}{lcccc}
\hline \multirow{2}{*}{ Nutrient } & \multicolumn{4}{c}{ Ingredient } \\
\cline { 2 - 5 } & Sugarcane & Corn & Soybean & BMB \\
\hline Dry matter (g/kg as fed) & 256.50 & 877.80 & 884.80 & 880.50 \\
Ash & 35.00 & 26.20 & 73.10 & 61.90 \\
Crude protein & 30.80 & 91.00 & 487.60 & 37.30 \\
Ether extract & 12.70 & 41.80 & 17.50 & 14.10 \\
Neutral detergent fiber & 557.20 & 143.90 & 153.70 & 461.40 \\
Total carbohydrates & 925.70 & 845.80 & 431.20 & 886.70 \\
Non-fibrous carbohydrates & 363.00 & 686.40 & 287.50 & 432.30 \\
\hline
\end{tabular}

BMB - babassu mesocarp bran.

Table 2 - Proportion of ingredients in the diets $(\mathrm{g} / \mathrm{kg}$ of dry matter)

\begin{tabular}{lcccccc}
\hline \multirow{2}{*}{ Item } & \multicolumn{2}{c}{ High sugarcane $^{1}$} & & \multicolumn{2}{c}{ Low sugarcane $^{2}$} \\
\cline { 2 - 3 } \cline { 6 - 7 } & $420-\mathrm{BMB}$ & $620-\mathrm{BMB}$ & & 420-BMB & 620 -BMB \\
\hline Fresh sugarcane & 580.00 & 580.00 & & 380.00 & 380.00 \\
Ground corn & 115.10 & 74.30 & & 245.70 & 158.20 \\
Soybean meal & 206.70 & 212.70 & & 182.80 & 196.50 \\
BMB & 77.00 & 111.80 & & 164.30 & 238.10 \\
Mineral mixture & 12.70 & 12.70 & & 18.80 & 18.80 \\
Urea & 8.50 & 8.50 & & 8.40 & 8.40
\end{tabular}

BMB - babassu mesocarp bran.

${ }^{1}$ High sugarcane: $580 \mathrm{~g} \mathrm{~kg}^{-1}$ of sugarcane in the diets with 420 or $620 \mathrm{~g} \mathrm{~kg}^{-1}$ of BMB in the concentrate (dry matter basis).

${ }^{2}$ Low sugarcane: $380 \mathrm{~g} \mathrm{~kg}^{-1}$ of sugarcane in the diets with 420 or $620 \mathrm{~g} \mathrm{~kg}^{-1}$ of BMB in the concentrate (dry matter basis).

${ }^{3}$ Composition: P, 40 g; Ca, 146 g; Na, 56 g; S, 40 g; Mg, 20 g; Cu, 350 mg; Zn, 1,300 mg; Mn, 900 mg; Fe, 1,050 mg; Co, 10 mg; I, 24 mg; Se, 10 mg; F (maximum), $400 \mathrm{mg}$; excipient q.s., $1,000 \mathrm{mg}$. 
Standard procedures of AOAC (1990) were adopted to obtain the following components from the feed, orts, and fecal samples: dry matter, mineral matter (MM), crude protein $(\mathrm{CP})$, and ether extract (EE). Neutral detergent fiber (NDF) was determined according to Van Soest et al. (1991). Total carbohydrates (TC), non-fibrous carbohydrates (NFC), and total digestible nutrients (TDN) were estimated according to Sniffen et al. (1992), as follows: TC $=1000-$ $(\mathrm{CP}+\mathrm{EE}+\mathrm{MM}) ; \mathrm{NFC}=1000-(\mathrm{TC}-\mathrm{NDF}) ;$ and $\mathrm{TDN}=$ digestible $\mathrm{CP}+($ digestible $\mathrm{EE} \times 2.25)+$ digestible $\mathrm{NDF}+$ digestible TC. The metabolizable energy (ME) of the diets was estimated considering $1 \mathrm{~kg}$ TDN $=4.4 \mathrm{Mcal}$ digestible energy and $1 \mathrm{Mcal}$ of digestible energy $=0.82 \mathrm{Mcal}$ of ME (Table 3).

At the end of the feedlot period, animals were slaughtered at a commercial slaughterhouse under supervision of the Federal Inspection Service. Prior to the slaughter, animals were fasted for 14-16 $\mathrm{h}$. The carcasses were identified, divided in half, and weighed. After the carcasses were washed and kept in a cold chamber for $24 \mathrm{~h}$ at a temperature varying between 0 and $2{ }^{\circ} \mathrm{C}$, they were weighed again. The right half carcass was sectioned between the 11th and 12th ribs, exposing the longissimus dorsi muscle, in which the subcutaneous fat thickness was determined. The left half of the carcass was separated into primal cuts, with the forequarter separated from the pistol cut and short ribs between the 5th and 6th ribs, including neck, shoulder, arm, and five ribs. Through the rib cut at $22 \mathrm{~cm}$ from the spine, the pistol cut was separated from the short ribs, including the ones from the sixth ribs onwards, plus the abdominal muscles.

The experimental design was completely randomized, with treatments distributed in a $2 \times 2$ factorial arrangement, with six replicates. Data were subjected to analysis of variance by the mixed-model methodology (Littell et al., 2006), in which the model included the fixed effect of treatment and random effects of animal. Means were compared by Tukey's test $(\alpha=0.05)$. Statistical procedures were carried out using SAS software (Statistical Analysis System, version 9.1). The general mathematical model was represented by:

$$
\mathrm{Y}_{\mathrm{ijk}}=\mu+\mathrm{T}_{\mathrm{i}}+\mathrm{M}_{\mathrm{j}}+\mathrm{T}_{\mathrm{i}} \times \mathrm{M}_{\mathrm{j}}+\beta_{1} \mathrm{X}_{\mathrm{ij}}+\mathrm{e}_{\mathrm{ijk}} \text {, }
$$

in which $\mu$ is a constant, $T_{i}$ is the effect of the sugarcane proportion, $M_{j}$ is the effect of the BMB level, $T_{i} \times M_{j}$ is the effect of the interaction between the factors of variation, $\beta_{1} X_{\mathrm{ij}}$ is the effect of the covariate (initial body weight), and $\mathrm{e}_{\mathrm{ijk}}$ is the residual random error. When not significant, the effect of the covariate was withdrawn from the model.

\section{Results}

There was no interaction $(\mathrm{P}>0.05)$ between the proportion of sugarcane in the diet and level of inclusion of BMB in the concentrate on the evaluated variables, except for apparent digestibility of NDF. The intakes of DM, EE, and TDN were not affected by the treatments (Table 4). Crude protein intake was only changed by the proportion of sugarcane in the diet, with higher values found in animals on the treatments with a higher proportion of this roughage. Neutral detergent fiber intake ( $\mathrm{kg} / \mathrm{day})$, on the other hand, was changed only by the level of BMB, with higher values detected for the diets with higher proportion of this byproduct. Neutral detergent fiber intake in $\mathrm{g} / \mathrm{kg}$ body weight varied depending on the variation factors; lower values were found with the diet that associated the lowest proportions of sugarcane and BMB.

Average daily gain and final body weight were not changed $(\mathrm{P}>0.05)$ by the proportion of sugarcane in the diet or level of BMB inclusion in the concentrate (Table 5). Feed conversion, likewise, was not altered by the proportion of sugarcane of the diet or BMB level in the concentrate. Carcass characteristics were not affected by the variation factors, except for subcutaneous fat thickness, which was higher in the diets with the lower roughage level.

Table 3 - Chemical composition of the diets ( $\mathrm{g} / \mathrm{kg}$ of dry matter)

\begin{tabular}{|c|c|c|c|c|}
\hline \multirow{2}{*}{ Item } & \multicolumn{2}{|c|}{ High sugarcane $^{1}$} & \multicolumn{2}{|c|}{ Low sugarcane ${ }^{2}$} \\
\hline & 420-BMB & $620-\mathrm{BMB}$ & 420-BMB & $620-\mathrm{BMB}$ \\
\hline Dry matter (DM) (g/kg as fed) & 526.90 & 525.2 & 654.90 & 652.40 \\
\hline Crude protein & 153.10 & 154.00 & 151.50 & 153.90 \\
\hline Ether extract & 14.40 & 13.70 & 14.00 & 15.30 \\
\hline Neutral detergent fiber & 413.40 & 428.10 & 351.70 & 389.70 \\
\hline Total carbohydrates & 784.30 & 782.80 & 782.80 & 774.00 \\
\hline Metabolizable energy (Mcal/kg of DM) & 2.12 & 2.06 & 2.15 & 2.13 \\
\hline
\end{tabular}

BMB - babassu mesocarp bran.

${ }^{1}$ High sugarcane: $580 \mathrm{~g} \mathrm{~kg}^{-1}$ of sugarcane in the diets with 420 or $620 \mathrm{~g} \mathrm{~kg}^{-1}$ of BMB in the concentrate (dry matter basis).

${ }^{2}$ Low sugarcane: $380 \mathrm{~g} \mathrm{~kg}^{-1}$ of sugarcane in the diets with 420 or $620 \mathrm{~g} \mathrm{~kg}^{-1}$ of BMB in the concentrate (dry matter basis). 


\section{Discussion}

The high passage rate of BMB has been reported as the main cause of the increase in DM intake in diets that include this byproduct (Miotto et al., 2013). In this study, the lack of variations in DM intake with inclusion of BMB might be associated with the inclusion levels of this byproduct that ranged from 7.7 to $11.18 \%$ and from 16.43 to $23.81 \%$ in the diets with high and low proportions of sugarcane, respectively. Changes in DM intake with the inclusion of BMB in the cattle diets were found when the levels of this byproduct reached values higher than $25 \%$ of the diet dry matter (Cruz et al., 2014; Alencar et al., 2015). The high indigestible fiber content and low passage rate of sugarcane may have contributed to the obtained results, altering the transit of BMB through the reticulorumen (reducing its output) due to fiber entanglement.

The similar DM intake for the proportions of sugarcane in the diets might be associated, in part, with the small particle size and high passage rate of BMB (Miotto et al., 2013), which possibly compensated for the lower passage rate of diets with the higher proportion of sugarcane. In general, cattle fed greater proportions of sugarcane have a lower DM intake, which reflects in the rumen fill caused by high indigestible fiber content and lower passage rate of feeds (Magalhães et al., 2006; Pires et al., 2010b). However,

Table 4 - Intake and apparent digestibility of nutrients according to variation factors

\begin{tabular}{|c|c|c|c|c|c|c|c|c|}
\hline \multirow{2}{*}{ Item } & \multicolumn{2}{|c|}{ High sugarcane $^{1}$} & \multicolumn{2}{|c|}{ Low sugarcane ${ }^{2}$} & \multirow{2}{*}{ CV $(\%)$} & \multicolumn{3}{|c|}{ P-value } \\
\hline & 420-BMB & 620-BMB & 420-BMB & 620-BMB & & Sugarcane (S) & BMB & $\mathrm{S} \times \mathrm{BMB}$ \\
\hline \multicolumn{9}{|c|}{ Intake (kg/day) } \\
\hline Dry matter & 7.82 & 8.48 & 8.63 & 8.30 & 12.09 & 0.449 & 0.690 & 0.241 \\
\hline Crude protein & 1.90 & 2.00 & 1.75 & 1.70 & 12.88 & 0.026 & 0.616 & 0.391 \\
\hline Ether extract & 0.08 & 0.08 & 0.08 & 0.09 & 13.03 & 0.184 & 0.258 & 0.631 \\
\hline Neutral detergent fiber & 3.13 & 3.55 & 3.07 & 3.27 & 11.72 & 0.278 & 0.046 & 0.497 \\
\hline Total digestible nutrients & 4.80 & 5.02 & 5.13 & 4.86 & 11.36 & 0.743 & 0.982 & 0.323 \\
\hline \multicolumn{9}{|c|}{ Intake ( $\mathrm{g} / \mathrm{kg}$ body weight) } \\
\hline Dry matter & 20.39 & 22.27 & 22.64 & 21.53 & 12.09 & 0.449 & 0.690 & 0.241 \\
\hline Neutral detergent fiber & 8.16 & 9.32 & 8.05 & 8.48 & 10.50 & 0.214 & 0.036 & 0.412 \\
\hline \multicolumn{9}{|c|}{ Apparent digestibility ( $\mathrm{g} / \mathrm{kg}$ dry matter) } \\
\hline Dry matter & 606.90 & 576.00 & 586.10 & 582.60 & 3.90 & 0.456 & 0.084 & 0.159 \\
\hline Neutral detergent fiber & 265.30 & 231.20 & 174.60 & 259.80 & 7.46 & $<0.001$ & $<0.001$ & $<0.001$ \\
\hline
\end{tabular}

BMB - babassu mesocarp bran; CV - coefficient of variation.

${ }^{1}$ High sugarcane: $580 \mathrm{~g} \mathrm{~kg}^{-1}$ of sugarcane in the diets with 420 or $620 \mathrm{~g} \mathrm{~kg}^{-1}$ of BMB in the concentrate (dry matter basis).

${ }^{2}$ Low sugarcane: $380 \mathrm{~g} \mathrm{~kg}^{-1}$ of sugarcane in the diets with 420 or $620 \mathrm{~g} \mathrm{~kg}^{-1}$ of BMB in the concentrate (dry matter basis).

Table 5 - Performance and carcass characteristic according to variation factors

\begin{tabular}{|c|c|c|c|c|c|c|c|c|}
\hline \multirow{2}{*}{ Item } & \multicolumn{2}{|c|}{ High sugarcane $^{1}$} & \multicolumn{2}{|c|}{ Low sugarcane $^{2}$} & \multirow{2}{*}{$\mathrm{CV}(\%)$} & \multicolumn{3}{|c|}{ P-value } \\
\hline & 420-BMB & 620-BMB & 420-BMB & 620-BMB & & Sugarcane (S) & $\mathrm{BMB}$ & $\mathrm{S} \times \mathrm{BMB}$ \\
\hline \multicolumn{9}{|c|}{ Animal performance } \\
\hline IBW & 320.75 & 322.00 & 319.75 & 322.08 & - & - & - & - \\
\hline FBW & 446.33 & 439.53 & 442.42 & 448.96 & 4.43 & 0.735 & 0.987 & 0.417 \\
\hline ADG & 1.49 & 1.41 & 1.44 & 1.52 & 16.00 & 0.728 & 0.958 & 0.423 \\
\hline $\mathrm{FC}$ & 5.28 & 6.16 & 6.02 & 5.52 & 12.51 & 0.863 & 0.514 & 0.302 \\
\hline \multicolumn{9}{|c|}{ Carcass characteristics } \\
\hline $\mathrm{HCW}$ & 244.45 & 237.64 & 248.12 & 246.27 & 4.83 & 0.217 & 0.380 & 0.613 \\
\hline $\mathrm{CCW}$ & 232.17 & 227.36 & 235.90 & 234.92 & 4.60 & 0.211 & 0.515 & 0.666 \\
\hline $\mathrm{HCY}$ & 0.457 & 0.541 & 0.561 & 0.548 & 2.66 & 0.091 & 0.128 & 0.643 \\
\hline $\mathrm{CCY}$ & 0.520 & 0.518 & 0.533 & 0.523 & 2.63 & 0.107 & 0.286 & 0.514 \\
\hline DL & 0.028 & 0.025 & 0.031 & 0.028 & 26.76 & 0.355 & 0.288 & 0.954 \\
\hline FT & 2.03 & 1.79 & 3.00 & 2.79 & 33.82 & 0.008 & 0.967 & 0.494 \\
\hline $\mathrm{F}$ & 0.399 & 0.409 & 0.407 & 0.408 & 2.45 & 0.389 & 0.204 & 0.207 \\
\hline SR & 0.108 & 0.102 & 0.107 & 0.108 & 6.06 & 0.378 & 0.284 & 0.266 \\
\hline $\mathrm{PC}$ & 0.492 & 0.486 & 0.485 & 0.485 & 1.70 & 0.112 & 0.564 & 0.593 \\
\hline
\end{tabular}

BMB - babassu mesocarp bran; IBW - initial body weight $(\mathrm{kg}) ; \mathrm{FBW}$ - final body weight (kg); ADG - average daily gain (kg/day); FC - feed conversion (kg dry matter/kg weight gain); HCW - hot carcass weight (kg); CCW - cold carcass weight; HCY - hot carcass yield (kg/kg); CCY - cold carcass yield; DL - drip loss (g/kg); FT - fat thickness (mm); $\mathrm{F}$ - forequarter $(\mathrm{kg} / \mathrm{kg}) ; \mathrm{SR}$ - short ribs $(\mathrm{kg} / \mathrm{kg}) ; \mathrm{PC}$ - pistol cut $(\mathrm{kg} / \mathrm{kg}) ; \mathrm{CV}$ - coefficient of variation.

${ }^{1}$ High sugarcane: $580 \mathrm{~g} \mathrm{~kg}^{-1}$ of sugarcane in the diets with 420 or $620 \mathrm{~g} \mathrm{~kg}^{-1}$ of BMB in the concentrate (dry matter basis).

${ }^{2}$ Low sugarcane: $380 \mathrm{~g} \mathrm{~kg}^{-1}$ of sugarcane in the diets with 420 or $620 \mathrm{~g} \mathrm{~kg}^{-1}$ of BMB in the concentrate (dry matter basis). 
according to Restle et al. (2012), when the roughage is of medium to low quality, but the energy level of the diets is not a limiting factor, DM intake tends to remain constant with the concentrate increase, which makes the results consistent.

The higher crude protein intake obtained with the diets with the higher proportion of sugarcane can be attributed to animal selectivity. Thus, in trying to maintain energy intake due to the increased roughage in the diets, the animals selected the more digestible feed fractions with higher energy contents and also the fractions with more protein (concentrated fraction). This hypothesis can be confirmed by the lower $(32.40 \%)$ crude protein content in the leftovers of animals fed diets with a higher proportion of sugarcane. Similarly, Suzuki et al. (2014) found an increased amount of large sugarcane particles in leftovers from non-lactating cows as the proportion $(0,3,5,10,15$, and $20 \%$ ) of this roughage replacing ryegrass silage was increased. Feed selectivity of the animal, on the other hand, may also have contributed to the similar feed intakes, as the intake of more digestible feed fractions may have benefited the passage rate in diets with the higher proportion of sugarcane.

The similar EE intake between the diets can be explained mainly by the similar DM intake. In addition, low levels of inclusion of BMB, which has a low EE content (Table 1), may have contributed to these results, as the diets with high levels of this byproduct showed no significant reduction of lipid fraction (Table 3). Miotto et al. (2013) and Santana et al. (2015), however, found that EE intake decreased when they replaced up to $100 \%$ and $42.24 \%$ of corn grain, respectively, by BMB, reflecting the reduction in DM intake and the lower EE content of $\mathrm{BMB}$ in relation to corn. For the use of sugarcane, on the other hand, the literature has shown, with a high frequency, that an increase in the proportion of sugarcane in cattle diet reduces EE intake as a result of the reduction of DM intake (Magalhães et al., 2004, 2006).

The higher NDF intake with BMB inclusion in the diet can be attributed to the high fiber content of the feed, which was consistent with results reported in the literature (Miotto et al., 2013; Cruz et al., 2014; Santana et al., 2015). However, the literature shows that, in general, an increase in the proportion of sugarcane in cattle diets reduces NDF intake due to the decrease in DM intake (Magalhães et al., 2004, 2006). It is noteworthy that, in all evaluated diets, NDF intake was lower ( 7.9 to $9 \mathrm{~g} / \mathrm{kg}$ body weight) than the normal range (11-13 $\mathrm{g} / \mathrm{kg}$ body weight) for the negative effect of rumen fill on feed intake to take place (Mertens, 1994). Furthermore, despite its high NDF content, BMB has a low contribution to the rumen fill effect because of the reduced particle size.

The similar TDN intake can be attributed mainly to the similar DM intake between diets. In addition, the higher digestibility of the fiber in the diets with higher proportions of sugarcane and BMB may have increased energy intake, contributing to prevent significant differences in relation to diets with higher concentrate. In diets with inclusion of BMB, energy intake is normally maintained by extending the feeding time (Cruz et al., 2012; Silva et al., 2012). However, in sugarcane-based diets, increasing the proportion of roughage usually reduces energy intake as a result of the reduction in DM intake, especially when the sugarcane reaches a proportion equal to or greater than $60 \%$ of the diet dry matter (Magalhães et al., 2006; Rotta et al., 2014; Salomão et al., 2015).

Inclusion of BMB increases the passage rate of the feed because of its small particle size, reducing the apparent digestibility of diets (Miotto et al., 2013). In this regard, the higher digestibility of the fiber fraction in the diets that associated the greater proportion of sugarcane and BMB inclusion level might be indicating a positive association effect of these feedstuffs on ruminal digestion, which was possibly associated with the reduction of the passage rate of BMB because of the greater amount of long fibers from diets with higher proportion of roughage. The inclusion of BMB appears to benefit the use of diets with higher proportions of sugarcane, as an increase in the proportion of this roughage in the diet of cattle has been associated with reduced digestibility because of their indigestible fiber content (Magalhães et al., 2004, 2006).

The similar animal performance for the different diets can be attributed to the similar DM intake and especially the similar energy intake. These results were similar to those presented by Barros et al. (2009), who found that sugarcane replacing sorghum silage $(0,30,70$, and $100 \%)$ did not affect animal performance. Rangel et al. (2010) evaluated diets with sugarcane associated with different levels of concentrate $(1.3,2.0$, and $2.7 \mathrm{~kg} /$ day $)$ relative to a diet based on corn silage with $1.3 \mathrm{~kg}$ /day of concentrate and found that an increase in the proportion of sugarcane in the diet reduced average daily gain; however, diets with $45 \%$ sugarcane provided similar ( $802 \mathrm{vs} 892 \mathrm{~g} /$ day) weight gains to dairy heifers compared with diets with corn silage.

As for the animal response to BMB inclusion in diets, the literature (Silva et al., 2012; Cruz et al., 2014; Santana et al., 2015) shows that when inclusion levels are low to moderate (226.8 to $422.4 \mathrm{~g} / \mathrm{kg}$ of the diet DM), no changes in animal performance are observed, reflecting the similar energy intake. Nevertheless, Miotto et al. (2013) 
and Alencar et al. (2015) showed that the average daily gain of feedlot cattle began to show a significant decline as the inclusion of BMB approached $500 \mathrm{~g} / \mathrm{kg}$ of diet dry matter, after which the energy intake did not support the maintenance of animal performance.

The similar feed conversion between BMB levels can be attributed, mainly, to the similar animal performance. These results were consistent with some reported in the literature (Silva et al., 2012; Cruz et al., 2014; Santana et al., 2015), which have demonstrated that when BMB inclusion levels are low to moderate, the lack of change in animal performance usually results in similar feed conversion, even when DM intake is changed. However, when the BMB inclusion levels reduced animal performance, which occurred for higher levels of BMB inclusion in this study, feed conversion increased (Miotto et al., 2013; Alencar et al., 2015). For the use of sugarcane, on the other hand, the obtained results were similar to those reported by Pinto et al. (2010), who evaluated different proportions of sugarcane replacing sorghum silage and found no changes in feed conversion of confined cattle, despite the lower weight gain in diets with sugarcane.

The higher carcass finishing in feedlot animals fed diets with a lower proportion of sugarcane can be explained by their higher energy content (Table 5). Moreover, the lack of variation for other carcass characteristics, according to the variation factors, can be attributed to the similar body weight at slaughter. Alencar et al. (2016) evaluated BMB inclusion $(0,12,24,35$, and $48 \%$ dry matter) in pearl millet grain-based diets and a standard corn grain-based diet and found no effect of BMB inclusion on carcass characteristics of feedlot cattle slaughtered at similar body weights. Santana et al. (2014) found that the main carcass quantitative characteristics were not changed by addition of $412.4 \mathrm{~g} / \mathrm{kg}$ of BMB to diets based on whole or ground corn grain. However, these authors found that BMB inclusion in whole-corn grain diets negatively affected carcass yield, the percentage of pistol cut, and the yield of this cut in relation to diets with ground corn.

Regarding the use of sugarcane, results were consistent with those obtained by Pinto et al. (2010), who did not find changes in weight or carcass composition by replacing sorghum silage with sugarcane. Likewise, Rotta et al. (2014) did not find changes in carcass weight, degree of fatness, yield, or cooling loss testing different sugarcane ratios in feedlot cattle diets, which can be attributed to similar slaughter weights. However, these researchers found that diets with different proportions of sugarcane provided worse results for carcass traits compared with diets with different proportions of corn silage, except for degree of fatness, which was similar between diets with the different proportions of roughage used.

\section{Conclusions}

Inclusion of babassu mesocarp bran enables the use of larger proportions of sugarcane as a result of increased digestibility of the fiber fraction of feedlot cattle diets without changing the animal performance or main carcass characteristics of economic importance.

\section{Acknowledgments}

We thank the Conselho Nacional de Pesquisa e Desenvolvimento Científico e Tecnológico (CNPq) for financial support.

\section{References}

Alencar, W. M.; Restle, J.; Missio, R. L.; Neiva, J. N. M.; Miotto, F. R. C. and Freitas, I. B. 2015. Feeding behavior and productive performance of steers fed pearl millet grain-based diets containing proportions of babassu mesocarp bran. Revista Brasileira de Zootecnia 44:425-433.

Alencar, W. M.; Restle, J.; Missio, R. L.; Neiva, J. N. M.; Miotto, F. R. C.; Santana, A. E. M.; Augusto, W. F.; Freitas, I. B. and Elejalde, D. A. G. 2016. Carcass and meat characteristics from dairy-origin steers fed with diets based on ground pearl millet grain, containing inclusion levels of babassu mesocarp meal. Semina Ciências Agrárias 37:449-460.

AOAC - Association of Official Analytical Chemistry. 1990. Official methods of analysis. 15th ed. AOAC International, Arlington, VA.

Barros, R. C.; Rocha Júnior, V. R.; Silva, F. V.; Alves, D. D.; Sales, E. C. J.; Franco, M. O.; Reis, S. T. and Souza, A. S. 2009. Cana-deaçúcar ou bagaço de cana amonizado com uréia em substituição à silagem de sorgo para bovinos de corte confinados. Revista Brasileira de Saúde e Produção Animal 10:278-292.

Casali, A. O.; Detmann, E.; Valadares Filho, S. C.; Pereira, J. C.; Henriques, L. T.; Freitas, S. G. and Paulino, M. F. 2008. Influência do tempo de incubação e do tamanho de partículas sobre os teores de compostos indigestíveis em alimentos e fezes bovinas obtidos por procedimentos in situ. Revista Brasileira de Zootecnia 37:335-342.

Cochran, R. C.; Adans, D. C.; Wallace, J. D. and Galyean, M. L. 1986. Predicting digestibility of different diets with internal markers: evaluation of four potential markers. Journal of Animal Science 63:1476-1483

Cruz, R. S.; Alexandrino, E.; Missio, R. L.; Neiva, J. N. M.; Restle, J.; Melo, J. C.; Sousa Júnior, A. and Resende, J. M. 2012. Feeding behaviors of feedlot bulls fed concentrate levels and babassu mesocarp meal. Revista Brasileira de Zootecnia 41:1727-1736.

Cruz, R. S.; Alexandrino, E.; Missio, R. L.; Restle, J.; Melo, J. C.; Paula Neto, J. J.; Neiva, J. N. M.; Mendes Filho, G. O.; Souza Júnior, A.; Duarte, T. D.; Rezende, J. M. and Marinho Silva, A. A. 2014. Desempenho bioeconômico de tourinhos alimentados com níveis de concentrado e farelo do mesocarpo de babaçu. Semina: Ciências Agrárias 35:2159-2174.

Cruz, R. S.; Alexandrino, E.; Missio, R. L.; Neiva, J. N. M.; Restle, J.; Melo, J. C.; Paula Neto, J. J.; Pereira da Silva, D.; Duarte, T. D. 
and Marinho Silva, A. A. 2015. Características das carcaças e carne de tourinhos Nelore alimentados com níveis de concentrado e farelo do mesocarpo de babaçu. Arquivo Brasileiro de Medicina Veterinária e Zootecnia 67:299-308.

Littell, R. C.; Milliken, G. A.; Stroup, W. W.; Wolfinger, R. D. and Schabenberger, O. 2006. SAS ${ }^{\circledR}$ for Mixed models. 2nd ed. SAS Institute Inc., Cary, USA.

Magalhães, A. L. R.; Campos, J. M. S.; Valadares Filho, S. C.; Torres, R. A.; Mendes Neto, J. and Assis, A. J. 2004. Cana-de-açúcar em substituição à silagem de milho em dietas para vacas em lactação: desempenho e viabilidade econômica. Revista Brasileira de Zootecnia 33:1292-1302.

Magalhães, A. L. R.; Campos, J. M. S.; Cabral, L. S.; Mello, R.; Freitas, J. A.; Torres, R. A.; Valadares Filho, S. C. and Assis, A. J. 2006. Cana-de-açúcar em substituição à silagem de milho em dietas para vacas em lactação: parâmetros digestivos e ruminais. Revista Brasileira de Zootecnia 35:591-599.

Mertens D. R. 1994. Regulation of forage intake. p.450-493. In: Forage quality, evaluation and utilization. Fahey Jr, G. C., ed. American Society of Agronomy, Madison, WI.

Miotto, F. R. C.; Restle, J.; Neiva, J. N. M.; Lage, M. E.; Castro, K. J. and Alexandrino, E. 2012. Farelo do mesocarpo de babaçu na terminação de tourinhos: características da carcaça e cortes secundários do traseiro especial. Ciência Animal Brasileira 13:440-449.

Miotto, F. R. C.; Restle, J.; Neiva, J. N. M.; Castro, K. J.; Sousa, L. F.; Silva, R. O.; Freitas, B. B. and Leão, J. P. 2013. Replacement of corn by babassu mesocarp bran in diets for feedlot young bulls. Revista Brasileira de Zootecnia 42:213-219.

Pinto, A. P.; Abrahão, J. J. S.; Marques, J. A.; Nascimento, W. G.; Perotto, D. and Lugão, S. M. B. 2010. Desempenho e características de carcaça de tourinhos mestiços terminados em confinamento com dietas à base de cana-de-açúcar em substituição à silagem de sorgo. Revista Brasileira de Zootecnia 39:198-203.

Pires, A. J. V.; Carvalho, G. G. P. and Ribeiro, L. S. O. 2010a. Chemical treatment of roughage. Revista Brasileira de Zootecnia 39:192-203.

Pires, A. V.; Susin, I.; Simas, J. M. C.; Oliveira Júnior, R. C.; Fernandes, J. J. R.; Araújo, R. C. and Mendes, C. Q. 2010b. Substituição de silagem de milho por cana-de-açúcar e caroço de algodão sobre o desempenho de vacas holandesas em lactação. Ciência Animal Brasileira 11:251-257.

Rangel, A. H. N.; Campos, J. M. S.; Oliveira, A. S.; Valadares Filho, S. C.; Assis, A. J. and Souza, S. M. 2010. Desempenho e parâmetros nutricionais de fêmeas leiteiras em crescimento alimentadas com silagem de milho ou cana-de-açúcar com concentrado. Revista Brasileira de Zootecnia 39:2518-2526.

Restle, J.; Missio, R. L.; Resende, P. L. P.; Silva, N. L. Q.; Vaz, F. N.; Brondani, I. L.; Alves Filho, D. C. and Kuss, F. 2012. Silagem de híbridos de sorgo associado a percentagens de concentrado no desempenho de novilhos. Arquivo Brasileiro de Medicina Veterinária e Zootecnia 64:1239-1245.

Rotta, P. P.; Valadares Filho, S. C.; Engle, T. E.; Costa e Silva, L. F.; Sathler, D. F. T.; Prado, I. N.; Bonafé, E. G.; Zawadzki, F. and Visentainer, J. V. 2014. The impact of dietary sugarcane addition to finishing diets on performance, apparent digestibility, and fatty acid composition of Holstein $\times$ Zebu bulls. Journal of Animal Science 92:2641-2653.

Salomão, B. M.; Valadares Filho, S. C.; Villela, S. D. J.; Santos, S. A.; Costa e Silva, L. F. and Rottan, P. P. 2015. Desempenho produtivo de bovinos alimentados com cana-de-açúcar com diferentes níveis de concentrado. Arquivo Brasileiro de Medicina Veterinária e Zootecnia 67:1077-1086.

Santana, A. E. M.; Neiva, J. N. M.; Restle, J.; Sousa, L. F.; Miotto, F. R. C.; Araújo, V. L.; Alencar, W. M. and Augusto, W. F. 2014. Babassu mesocarp bran levels associated with whole or ground corn grains in the finishing of young bulls: carcass and meat characteristics. Revista Brasileira de Zootecnia 43:607-617.

Santana, A. E. M.; Neiva, J. N. M.; Restle, J.; Miotto, F. R. C.; Sousa, L. F.; Araújo, V. L.; Parente, R. R. P. and Oliveira, R. A. 2015. Productive performance and blood parameters of bulls fed diets containing babassu mesocarp bran and whole or ground corn. Revista Brasileira de Zootecnia 44:27-36.

Silva, N. R.; Ferreira, A. C. H.; Faturi, C.; Silva, G. F.; Missio, R. L.; Neiva, J. N. M.; Araujo, V. L. and Alexandrino, E. 2012. Desempenho em confinamento de bovinos de corte, castrados ou não, alimentados com teores crescentes de farelo do mesocarpo de babaçu. Ciência Rural 42:1882-1887.

Sniffen, C. J.; O’Connor, J. D. O.; Van Soest, P. J.; Fox, D.G. and Russel, J. B. 1992. A net carbohydrate and protein system for evaluating cattle diets: II. Carbohydrate and protein availability. Journal of Animal Science 70:3562-3577.

Suzuki, T.; Sakaigaichi, T.; Mitsuru, K.; Kamiya, Y.; Hattori, I.; Sato, K.; Terauchi, T. and Tanaka, M. 2014. Feeding of fodder-sugarcane silage to holstein cows. Japan International Research Center of Agricultural Sciences 48:183-193.

Teixeira, M. A. 2008. Babassu - A new approach for an ancient Brazilian biomass. Biomass and Bioenergy 32:857-864.

Teixeira, M. A. and Carvalho, M. G. 2007. Regulatory mechanism for biomass renewable energy in Brazil, a case study of the Brazilian Babassu oil extraction industry. Energy 32:999-1005.

Valadares Filho, S. C.; Marcondes, M. I.; Chizzotti, M. L. and Paulino, P. V. R. 2010. Exigências nutricionais de zebuínos puros e cruzados. Editora UFV, Viçosa, MG. 194p.

Van Soest, P. J.; Roberttson, J. B. and Lewis, B. A. 1991. Methods for dietary fiber, neutral detergent fiber, and nonstarch polysaccharides in relation to animal nutrition. Journal of Dairy Science 74:3583-3597. 